коли воно поєднується, більше того «переливається» у самовиховання - таке кредо великого педагога У цьому інтимному внутрішньому процесі слід розгорнути такі душевні сили, які б викликали в дитини бажання бути кращою. I тут імпульсом до цього переживання має стати відкриття в іншій людині чогось морально досконалого і красивого. Тому дитині, що духовно зростає, конче потрібне духовно зріле оточення дорослих, яке оберігає іiї від усілякого зла, що присутнє в житті.
В. Сухомлинський залишив нам велику книгу виховання і наше завдання - глибоко опановуючи iï, торувати подальші шляхи до духовно-морального зростання нашої молоді.

\section{СПИСОК ВИКОРИСТАНОЇ ЛІТРАТУРИ}

1. Сухомлинський В. О. Батьківська педагогіка / В. О. Сухомлинський. - Київ : Рад. школа, 1978.

Дата надходження до редакиї: 30.08.2019 р.
УДК 371.48:37.091.4

DOI: $10.37026 / 2520-6427-2019-99-3-6-10$
Неллі БОНДАРЕНКО,

кандидатка педагогічних наук, старша наукова співробітниця відділу навчання української мови та літератури Інституту педагогіки НАПН України, м. Київ

\title{
НЕПРОМИНУЩЕ ЗНАЧЕННЯ ДОРОБКУ ВАСИЛЯ СУХОМЛИНСЬКОГО ДЛЯ РОЗБУДОВИ НОВОЇ УКРАЇНСЬКОЇ ШКОЛИ
}

У статті обтрунтовано непроминуще значення доробку украӥнського ученого-педагога і письменника Василя Сухомлинського для розвитку вітчизняноі освіти та науки. Виокремлено, проаналізовано й інтерпретовано з позичій сучасної педагогіки ідеї та положення, суголосні нинішньому реформуванню галузі й значущі для розбудови Нової украӥнської школи у контексті освітньої євроінтеграції. Розкрито иляхи їх імплементації. Визначено перспективи подальших досліджень доробку великого педагога в аспекті висхідного розвитку освітньої галузі.

Ключові слова: Василь Сухомлинський, доробок, запитаність ідей, освітня реформа, євроінтеграція, Нова українська школа, иляхи імплементації.

В статье обосновано непреходящее значение наследия украинского ученого-педагога и писателя Василия Сухомлинского для развития отечественного образования и науки. Выделены, проанализированы и интерпретированы с позииий современной педагогики идеи и положения, созвучные нынешнему реформированию отрасли и значимые для развития Новой украинской школы в контексте образовательной евроинтеграции. Раскрыты пути их имплементациии. Определены перспективы дальнейших исследований наследия великого педагога в аспекте прогрессивного развития образования.

Ключевые слова: Василий Сухомлинский, наследие, востребованность идей, образовательная реформа, евроинтеграция, Новая украинская школа, пути имплементации.
The article deals with the problem of modern interpretation of the achievements of the national education reformers, their prognostic ideas, promising developments and their involvement in the current educational reform. The world-wide importance of Vasyl Sukhomlinsky's work was emphasized, ideas and provisions of importance for the development of the New Ukrainian School in the context of educational European integration, prospects for the development of Ukrainian education and science were highlighted.

The works of scientists who have revealed the facets of the personality of the scientist-teacher and writer Vasyl Sukhomlinsky are analyzed; his creative achievements were systematically considered; stages of formation and essence of pedagogical system are revealed; noted the uniqueness of its formation based on the author's own experience within the authoritarian system against her; the leading positions of the scientific heritage of the scientist of the world scale are elucidated and modernly interpreted; their relevance for reforming Ukrainian education and science in the context of European integration has been proved; practical recommendations for the implementation of ideas in the practice of the modern school have been developed.

In the sphere of attention of the scientist-teacher Vasyl Sukhomlinsky were such important problems as the theory and practice of teaching and upbringing; all aspects of education; folk pedagogy; compulsory skills; reading; child development; formation of creative personality; expanding and changing the quality of the educational space; value development of personality; 
verbal creativity; culture of word and thought; pedagogy of success; philosophy of childhood; harmonizing family, society and school; multi-age pedagogy; collective formation on the basis of human relations; self-education; activity and pedagogical skill of the teacher, his interaction with students, etc.

Key words: Vasyl Sukhomlinsky, achievements, questioning of ideas, educational reform, European integration, New Ukrainian School, ways of implementation.

Постановка проблеми. Україна має привілей пишатися визначними митцями педагогіки. Саме митцями, адже педагогіка - то не лише наука, а й «мистецтво передавати нащадкам досвід, накопичений людством і нацією, й головне - дати вміння жити серед людей» $[9$, с. 21].

Такі визначні постаті в педагогічному сузір'ї нашої держави, як Григорій Сковорода, Костянтин Ушинський, Христина Алчевська, Михайло Драгоманов, Софія Русова, Григорій Ващенко, Антон Макаренко, Василь Сухомлинський, Іван Зязюн та інші жертовно працювали, щоб нині Україна могла здійснити квантовий стрибок у європейський освітній простір.

Доктринальні зрушення у сфері освіти розпочалися із прийняттям Концепції «Нова українська школа» (2016) і Закону України «Про освіту» (2017), у статті 6 якого визначено засади державної політики у сфері освіти. Вони грунтуються на засадничих ідеях видатних українських педагогів-просвітителів. Основні з-поміж них - людиноцентризм, висока якість освіти, рівний доступ до неї, однакові можливості для всіх, інклюзивна освіта, науковість, різноманітність, цілісність і наступність освіти, інтеграція з ринком праці, нерозривність із національною та світовою історією, культурою, традиціями; гуманізм, демократизм, гармонійний розвиток особистості, єдність навчання, виховання і розвитку, культивування патріотизму, поваги до культурних цінностей українського народу, його історико-культурного надбання і традицій, формування потреби в дотриманні Конституції і законів України, поваги до прав і свобод людини, формування громадянської культури та культури демократії, здорового способу життя, екологічної культури, зближення школи й родини, інтеграція в освітній і науковий простір тощо [1-3; 5].

Освітня євроінтеграція, якій передує реформування української освіти за світовим зразком, передбачає увідповіднення стандартам найуспішніших країн. 3 іншого боку, в багатьох світових освітніх інноваціях простежується український слід, хоча дехто вважає їх чужим винаходом. Вітчизняні освітні інновації охоплюють інтелектуальний, фізичний, естетичний, моральний розвиток дитини, аспекти розвивального, діалогового, особистісно орієнтованого навчання, формування виховних систем тощо. Тому доктринальні зміни в освіті пріоритетизують національний інтерес і спонукають звернутися до спадку вітчизняних реформаторів, які зробили вагомий внесок у розвиток української і світової освіти і науки.

Одна $з$ яскравих постатей - Василь Олександрович Сухомлинський, фундатор світоглядних засад засновник гуманістичної національної новаторської педагогіки (1918-1970), визначний теоретик та експериментатор, людина різнобічних інтересів, ерудит, інтелігент, еліта, совість нації. Його творчість - невичерпне джерело сучасних пророчих педагогічних ідей, актуальних для сьогодення і прийдешнього.
Видатний український педагог стверджував, що «за маленькою шкільною партою твориться народ», а «людина - найвища цінність серед усіх цінностей світу» $[8$, т. 5 , с. 412$]$.

Василь Сухомлинський - автор 36 монографій i брошур, понад 600 статей, близько півтори тисячі оповідань і казок для дітей і підлітків. Учений-педагог був прибічником розумного і прогнозованого реформування. Він став «хрещеним батьком» Нової української школи. Значущість доробку Василя Сухомлинського актуалізувалася з огляду на послаблення гуманітарної складової в умовах глобалізації, технократизації й інформатизації суспільства, дефіциту моралі, загострення проблем національної ідентичності й виховання.

Аналіз наукових досліджень і публікацій. Безцінну педагогічну спадщину В. О. Сухомлинського у річищі прогресивного розвитку вітчизняної освіти і науки різноаспектно досліджували М. Антонець, Г. Бондаренко, Н. Бондаренко, А. Борисовський, Т. Будняк, Г. Волков, К. Григор'єв, І. Зязюн, В. Кіндрат, Т. Кочубей, М. Красовицький, К. Кривошеєнко, В. Кузь, В. Лоскутов, А. Луцюк, Л. Мамчур, С. Мiхелі, Л. Петрук, О. Савченко, О. Сараєва, В. Святовець, А. Семез, С. Соловейчик, М. Стельмахович, В. Степанова, О. Сухомлинська, І. Сюндюков, Г. Ткаченко, Л. Ткачук, М. Ярмаченко.

У їхніх працях вияскравлено найвартісніші грані особистості Великого Українця; з'ясовано суспільно-історичну значущість його ідей; системно розглянуто творчий доробок видатного педагога; розкрито етапи становлення й сутність педагогічної системи Василя Сухомлинського; акцентовано іï особливості в контексті розвитку освіти й педагогічної думки; розроблено практичні рекомендації щодо впровадження пророчих ідей українського генія в практику сучасної школи.

Дослідження й публікації неспроможні охопити всього обширу й діапазону ідей, на які багатий творчий доробок Василя Сухомлинського. В об'єктиві уваги дослідників - сучасно інтерпретовані аспекти виховання - національне, патріотичне, громадянське, моральне, розумове, трудове, естетичне; теорія і практика навчання й виховання; народна педагогіка; загальнообов'язкові критичні навички; читання; робота 3 текстом; інформаційна грамотність; розвиток дитини; формування творчої особистості; розширення і зміна якості освітнього простору; ціннісний розвиток особистості; словесна творчість; культура слова й думки; виховання засобами слова; лінгводидактичні аспекти сухомлинськознавства; педагогіка успіху; філософія дитинства; гармонізація сім’і та школи; різновікова педагогіка; колективоутворення на засадах людяних стосунків і учнівського самоврядування; самовиховання; діяльність і педагогічна майстерність учителя, його взаємодія з учнями тощо. Саме на основі теоретичних напрацювань Василя Сухомлинського та інших корифеїв вітчизняної педагогіки було розроблено цілісну модель виховання, що грунтується на ціннісному ставленні до себе, до сім'ї та родини; до суспільства й держави; до праці; до природи; до культури й мистецтва.

Мета статті - розкрити основні положення доробку вченого-педагога світового масштабу Василя Сухомлинського, показати їх актуальність для реформування української освіти і науки у контексті євроінтеграції. 
Виклад основного матеріалу. Особлива цінність, стійкість і унікальність педагогічної системи Василя Сухомлинського полягає в тому, що вона сформувалася на фундаменті його власного досвіду всупереч авторитарній радянській системі. Він творив у річищі вітчизняної освіти, яка саме завдяки таким особистостям розвивалася на збалансованому співвідношенні сформованого віками традиційного, національного, i нового (не обов'язково запозиченого).

Нагальна потреба у зверненні творців Нової української школи до спадку Василя Сухомлинського зумовлена тим, що іще півстоліття тому великий педагог утвердив основні принципи школи майбутнього. Це: людиноцентрованість; оптимістичне світосприймання; культ книги й читання; розвиток системного мислення; нова якість спілкування; побудова гармонійних стосунків між людьми; формування учнівського й педагогічного колективу; різновікове колективоутворення; навчання для життя; високий авторитет учителя; демократизм; якісно нова взаємодія вчителя й учнів; повага до учня; педагогічна культура; пріоритет знань як основи умінь і навичок; переростання знань у переконання через їх передавання і збагачення ними інших; розвиток найвартісніших людських якостей; нетерпимість до зла; виховання правдою; гуманізація особистості через творення добра; формування дбайливого ставлення до природи та її багатств; виховання культури бажань; урівноваження матеріальних і духовних потреб; розвиток емоційної сфери; професійне самовизначення; гармонізація стосунків у сім'ї; «співдружність родини та школи»; навчання батьків, їх активна участь у житті школи тощо.

Василь Сухомлинський визначив критичні вміння, які необхідно сформувати кожному учневі. Вони $€$ елементами ключових і предметних компетентностей у їх сучасному трактуванні і торкаються мотиваційної, когнітивної та емоційної сфер, розвитку критичного системного мислення, вільного володіння державною мовою, здатності ефективно використовувати мови, вміння здобувати, накопичувати й обробляти інформацію; застосовувати мисленнєві операції та логічне мислення до розв'язання проблем, навчання упродовж життя, здатності виявляти, оцінювати й реалізовувати свої можливості тощо. Визначені в Законі України «Про освіту» ключові компетентності, сформовані на грунті цих умінь, $є$ передумовою європеїзації освітянської галузі в Україні.

Отже, Василь Сухомлинський виділяе такі вміння: 1) спостерігати за довкіллям; 2) думати - зіставляти, порівнювати, протиставляти, знаходити незрозуміле; вміння дивуватися; 3) висловлювати думку про те, що бачить учень, за чим він спостерігає та що робить; 4) виразно читати в належному темпі; 5) правильно і швидко писати; 6) виділяти логічно завершені частини у прочитаному, встановлювати взаємозв'язки між ними; 7) знаходити книги 3 питання, що цікавить; 8) відшукувати в книзі необхідний матеріал; 9) робити попередній логічний аналіз у процесі читання; 10) слухати вчителя та одночасно стисло записувати зміст його розповіді; 11) читати текст і одночасно слухати інструктаж учителя про роботу над текстом, над логічними частинами; 12) написати твір розповісти про те, що учень бачить навколо себе, що спостерігає та ін. [4, с. 55].

За задумом Василя Сухомлинського, формуванню зазначених умінь мала сприяти спеціально облаштована «кімната думки», яка цілком виправдала сподівання.
Учений-педагог і письменник укомплектував її «золотою бібліотекою юнацтва», яка складалася із 360-ти книг класиків світової та української літератури як іï невід'ємного складника. Представник справжньої національної еліти, інтелігент, інтелектуал, він сам вивчав світові надбання. Кімната стала осередком духовності й інтелектуального життя школи, де діти читали й обговорювали книги, дискутували, де зароджувалися нові ідеї. Великий педагог уважав: якщо в початковій школі діти мало читали, то в них складається структура малодіяльного мозку. 3 огляду на потужну пізнавальну, розвивальну й духовну силу книги Василь Сухомлинський і батькам учнів радив збирати бібліотеки для дітей. Очевидно, що культ книги, яким так були захоплені українські вчителі у Фінляндії, понад півстоліття тому вже панував у Павлиській школі, а якщо піти вглиб історії то в часи Ярослава Мудрого, який зібрав безцінну бібліотеку, розшукувану й досі.

Ця втілена в життя самим Сухомлинським його ідея, підхоплена цілим світом, як і уроки мислення серед природи і звичайні уроки просто неба, була передвісницею цілого напряму реформування школи - створення якісно зміненого освітнього простору. Вона суголосна 3 Проектом «Новий освітній простір», який реалізується в Україні із 2016 року в рамках розбудови Нової української школи. За задумом його авторів, цей необмежений школою простір має бути розумним, пізнавальним, доцільним, креативним, комфортним і яскравим. Будівництво нових шкіл за принципами нового освітнього простору відзначається незвичним інтер'єром. Кожен клас тут інший і має свою тематику. Стіни рекреацій дотепно і яскраво розмальовані. Натомість ідею створення нового освітнього простору дехто необізнаний з історією вітчизняної педагогіки чомусь вважає закордонним запозиченням.

Василь Сухомлинський започаткував особистісно орієнтований підхід в освіті на противагу авторитарному. Ініціювавши більш ранне навчання дітей, із 6-річного віку, він розробив унікальний - цікавий, життєвідповідний і сучасний на віки - зміст нової науки - науки формування Людини. I тут проявився письменницький талант багатогранного генія Василя Сухомлинського. Його оповідання й казки (а їх до півтори тисячі) ініціатори створення Конституції Цінностей можуть узяти за основу проекту. Бо немає жодної обійденої увагою цінності, найвищої моральної якості, яку письменник не розкрив би в цікавому захопливому сюжеті. На простих і зрозумілих дітям прикладах із реального життя автор роз'яснює причини, суть і наслідки негідних учинків та розкриває цінність і красу високоморальних, які йдуть із народних глибин. Кожне оповідання чи казка Василя Сухомлинського - це уроки Людяності, які крок за кроком наближають до мети - становлення Справжньої Людини. Його «Казки Школи під Голубим Небом», «Чиста криниця» - підручники, як стати Людиною й залишитися нею за будь-яких обставин. I його книги про любов не вичерпуються однойменним виданням 1983-го року. Про любов до Людини - усі без винятку книги Василя Сухомлинського. Мотиви людяності й усепереможного Добра пронизують читанки на основі роботи з його творами.

Цінність творів Василя Сухомлинського для дітей кратно зростає з огляду на те що початкова освіта 
$€$ фундаментом, на якому грунтуються всі наступні рівні освіти, де учні продовжують опановувати безцінну для формування особистості творчу спадщину Великого Педагога.

У новітню електронну добу, епоху Інтернету, коли цінності відступають на задній план перед прагматизмом, а діти втрачають інтерес до читання - однієї 3 ключових навичок XXI століття - спадщина Василя Сухомлинського як письменника набуває особливої актуальності. Адже читання, вміння здобувати, обробляти й використовувати інформацію, збагачуватися ціннісно $є$ складниками більшості ключових компетентностей, які має сформувати Нова українська школа. Твори Василя Сухомлинського для дітей, підлітків і юнацтва позбавлені моралізаторства. Вони вирізняються переконливістю, гуманістичною змістовністю, глибиною і багатошаровістю (кількістю рівнів, на яких вони можуть бути прочитані). Така багатоярусність дає змогу, перечитуючи тексти, відкривати в них нові смисли й базові цінності.

Великої ваги надавав Василь Сухомлинський опануванню наукових знань, без яких неможливі ані формування згаданих раніше критичних умінь (читай: ключових компетентностей), ані праця, ані культура людських стосунків, ані виконання громадських обов'язків [7, с. 70]. На такій самій позиції стоять сучасні науковці, які «застерігають від протиставлення знаннєвої, або фактоорієнтованої, й компетентнісної освіти. Щоб легко адаптуватися і якомога краще жити й діяти в сучасному світі, про нього треба багато знати. Лише знання є субстратом для мислення. Якщо людині бракує знань, то їй немає про що думати. Тому знання можна зарахувати до ядра ключових компетентностей» [2, с. 129]. Великий педагог слушно вважав, що найглибшими і найбільш тривкими $€$ знання, здобуті самостійно. У Концепції Нової української школи формуванню самостійності приділено особливу увагу.

Учні Павлиської школи не лише здобували знання на уроках і в науково-предметних гуртках, що були прообразами профільного навчання, а й влаштовували вечори знань для людей старшого віку. Педагог стверджував, що саме завдяки процесу передавання знань і прагненню сприяти освіченості інших людей знання перетворюються на переконання.

Неабиякого значення надавав Сухомлинський розумовому розвиткові учнів, формуванню у них інтелектуальних умінь, які відтворюють мислення (здатність зіставляти, порівнювати, структурувати, аналізувати, узагальнювати, класифікувати, синтезувати, моделювати тощо). Суголосно Аристотелю він уважав, що «мислення починається із запитання, зі здивування» [6, с. 254]. Це положення корелюється iз переліком найважливіших навичок XXI століття, коли здатність ставити доцільні запитання не менш важлива, ніж самі відповіді.

Василь Сухомлинський проводив щоденні невимушені бесіди з учнями на природі ще задовго до того, як фіни, чий нібито досвід ми переймаємо, зобов'язали кожного вчителя виголошувати 4-5 разів на рік 10-хвилинні промови перед учнями й колегами на теми моралі, що спонукало б їх задуматися (лишень замислитися?) над цінностями. «Виховуй у собі Людину - ось що найголовніше. Інженером можна стати за п'ять років, учитись на Людину треба все життя», - наставляв Василь Сухомлинський.
На понад півстоліття випередивши фінів, учений-педагог уважав, що максимального успіху можна досягти лише об'єднавши зусилля школи, вулиці, родини і всього суспільства. 3 переконання, що «вихователь сам має бути вихований», створив у Павлиші першу в СРСР спеціалізовану «школу для батьків», яка перевершила очікування.

Висновки. Отже, звернення освітян до спадщини Василя Сухомлинського в умовах нинішнього реформування галузі зумовлене ії високим гуманістичним, інноваційним та прогностичним потенціалом, потребою актуалізувати перспективні ідеї, аспекти і напрями вітчизняного досвіду в умовах освітньої євроінтеграції й розбудови Нової української школи. Це дасть змогу підняти освіту на якісно вищий щабель розвитку.

Перспективи подальших досліджень доробку Василя Сухомлинського вбачаємо у виявленні, сучасному трактуванні й реалізації перспективних ідей i смислів, закладених у багатошаровій науковій i письменницькій спадщині українського ученого-педагога світового виміру.

\section{СПИСОК ВИКОРИСТАНОЇ ЛІТЕРАТУРИ}

1. Бондаренко Н. В. Українська нова школа у контексті світових трендів освіти / Н. В. Бондаренко // Science progress in European countries: new concepts and modern solutions»): papers of the $7^{\text {th }}$ International Scientific Conference (May 31, 2019). - Stuttgart, Germany : ORT Publishing, 2019. - S. 304-316.

2. Бондаренко Н. В. Компетентнізація шкільної освіти: українська версія. Science and society / Н. В. Бондаренко // Proceedings of the $13^{\text {th }}$ International conference (July 19, 2019). Accent Graphics Communications \& Publishing. - Hamilton, Canada. 2019. - P. 124-135.

3. Бондаренко Н. В. Цінності об'єднаної Європи та їх формування в Українській новій школі / Н. В. Бондаренко // Science progress in European countries: new concepts and modern solutions») : papers of the $8^{\text {th }}$ International Scientific Conference (July 12, 2019). - Stuttgart, Germany. Ed. by L. Siebenberg. Stuttgart : ORT Publishing, 2019. - P. 62-74.

4. Борисовский А. М. В. А. Сухомлинский : кн. для учащихся / А. М. Борисовский. - Москва : Просвещение, 1985. - 128 с.

5. Закон України «Про освіту» [Електронний ресурс] // Відомості Верховної Ради. - 2017. - № 38-39. URL:http://zakon0.rada.gov.ua/laws/show/2145-19 (дата звернення: 20.07.2019).

6. Історія педагогіки України в особах : навч. посіб. / В. А. Мосіяшенко, О. І. Курок, Л. В. Задорожна. Суми : Університетська книга, 2012. - 266 с.

7. Родчанин Е. Г. Гуманист. Мыслитель. Педагог. Об идеалах В. А. Сухомлинского / Е. Г. Родчанин, И. А. Зязюн. - Москва : Педагогика, 1991. - 112 с.

8. Сухомлинський В. О. Вибрані твори : в 5 т. / В. О. Сухомлинський. - Київ : Рад. шк., 1977. $670 \mathrm{c}$.

9. Сюндюков I. Наш Учитель. Нова українська школа 100-річної давнини: настанови Василя Сухомлинського / І. Сюндюков // День. - 2018. - 28-29 вер. (№ 175/176). - C. 21.

Дата надходження до редакиіï: 06.08.2019 p. 